University of Nebraska - Lincoln

DigitalCommons@University of Nebraska - Lincoln

Other Publications in Zoonotics and Wildlife

Disease

Wildlife Disease and Zoonotics

2004

Histamine as an aid to biopsy of third eyelid lymphoid tissue in sheep

S. Bender

Navajo Nation Veterinary Program

J. Alverson

DVM

L. M. Herrmann

Katherine I. O'Rourke

U.S. Department of Agriculture, katherine.orourke@ars.usda.gov

Follow this and additional works at: https://digitalcommons.unl.edu/zoonoticspub

Part of the Veterinary Infectious Diseases Commons

Bender, S.; Alverson, J.; Herrmann, L. M.; and O'Rourke, Katherine I., "Histamine as an aid to biopsy of third eyelid lymphoid tissue in sheep" (2004). Other Publications in Zoonotics and Wildlife Disease. 155.

https://digitalcommons.unl.edu/zoonoticspub/155

This Article is brought to you for free and open access by the Wildlife Disease and Zoonotics at DigitalCommons@University of Nebraska - Lincoln. It has been accepted for inclusion in Other Publications in Zoonotics and Wildlife Disease by an authorized administrator of DigitalCommons@University of Nebraska - Lincoln. 


\section{Histamine as an aid to biopsy of third eyelid lymphoid tissue in sheep}

\section{S. Bender, J. Alverson, L. M. Herrmann, K. I. O'ROURKE}

TRANSMISSIBLE spongiform encephalopathies, of which ovine scrapie is a prototype, are neurodegenerative disorders characterised by the accumulation of an abnormal isoform (PrP-scrapie or $\mathrm{PrP}^{\mathrm{Sc}}$ ) of a normal cellular protein $\left(\mathrm{PrP}^{\mathrm{c}}\right)$ (Prusiner 1982). Characteristics of the disease include long incubation periods, and a progressive and chronic clinical course resulting in death (Fraser 1976). $\mathrm{PrP}^{\mathrm{Sc}}$ is detectable during the preclinical stages of scrapie in peripheral lymph nodes (Ikegami and others 1991, Muramatsu and others 1993), in lymphoid follicles of the tonsils (Schreuder and others 1996) and in lymphoid follicles of the nictitating membrane or third eyelid (O'Rourke and others 1998b).

Diagnosis of scrapie in sheep by third eyelid lymphoid tissue biopsy and $\mathrm{PrPSc}$ assay, as described by O'Rourke and others (1998b, 2000), is a practical test for live sheep and is useful for the preclinical diagnosis of scrapie in surveillance programmes (O'Rourke and others 2002). Although the lymphoid tissue of the third eyelid is accessible and can be anaesthetised locally, one obstacle to using this diagnostic test is obtaining third eyelid samples with sufficient numbers of lymphoid follicles to enable accurate scrapie diagnosis. This is complicated by the irregular distribution of the lymphoid tissue within the third eyelid and the sparse amount of lymphoid tissues in older sheep. A previous study reported lymphoid follicle mean (se) numbers of $0.7(0 \cdot 16), 0.78(0.27)$ and $5.32(0.7)$ in three areas of the third eyelids of sheep (Thuring and others 2000). Suitable samples must contain at least six lymphoid follicles per section for the diagnosis of scrapie (O'Rourke and others 2002). This short communication reports an improved third eyelid sampling technique using histamine/proparacaine eye drops.

A field trial was conducted on 78 sheep from a Navajo reservation flock in Alamo, New Mexico, using an eye drop formulation of 1 per cent histamine and 0.5 per cent proparacaine hydrochloride in an aqueous base (Vetricare) before third eyelid biopsy. Seventy-six of the sheep ( 97.4 per cent) provided sufficient numbers of lymphoid follicles in their third eyelids. No adverse reactions to the histamine or biopsy procedure, such as photophobia, increased attraction of flies, excessive tearing or bleeding from the biopsy site, or anorexia, were noted on the day of testing or during follow-up care conducted on site the next day. The flock was checked on a regular basis for the following 12 months and no adverse reactions from the biopsy protocol were noted. Five additional sheep flocks on the Navajo Nation reservation have been third eyelid tested to date using the histamine/proparacaine eye drops. The only reported side effect has been mild bleeding from the biopsy site in a small number of sheep. In each of these cases, the bleeding stopped within a few minutes.

In total, 131 sheep were biopsied using the histamine/ proparacaine drops, of which 13 gave insufficient numbers of follicles for scrapie diagnosis. Data from 53 control sheep, which had been biopsied with proparacaine drops alone with the use of no added histamine, showed 16 biopsy samples with insufficient numbers of follicles for scrapie diagnosis. An analysis of these data show that the success rate for obtain-
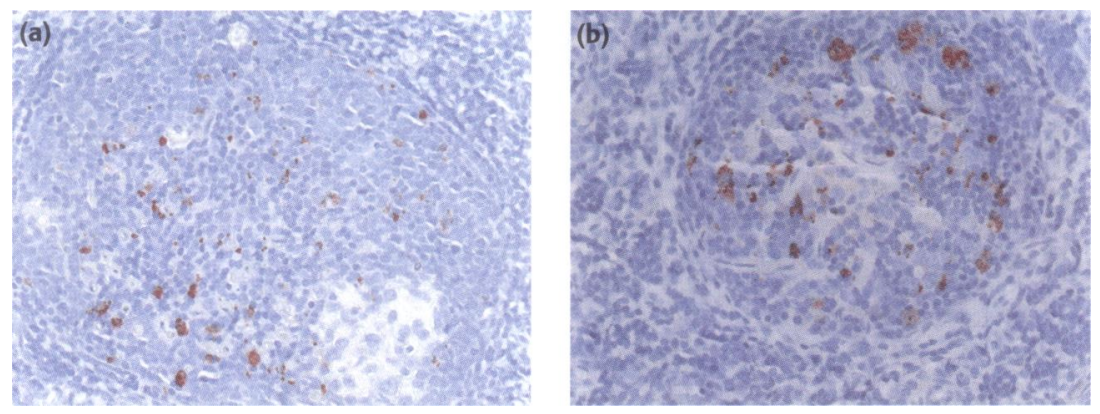

FIG 1: Immunoreactivity for PrPSc (red) detected in lymphoid tissue of third eyelids treated (a) without and (b) with histamine-containing eye drops. $x 40$

ing third eyelid biopsy samples with sufficient lymphoid follicles for scrapie diagnosis improved from approximately 70 per cent to 90 per cent with the use of the histamine/proparacaine drops.

The left and right third eyelids of five sheep from a scrapiepositive research flock were biopsied to test the histamine/ proparacaine eye drops with regard to interference with $\mathrm{PrP}^{\mathrm{Sc}}$ detection. The right eye of each sheep was treated with the histamine/proparacaine eye drops, while the left eye was treated with topical 0.5 per cent sterile ophthalmic proparacaine hydrochloride (Bausch and Lomb). The drops were applied approximately six minutes before the biopsy procedure was performed. The sheep were restrained manually in a semi-reclining position in a portable restraint apparatus similar to that used for hoof trimmings (Sheep Deck Chair; Premier 1). Third eyelid lymphoid tissue biopsy specimens were collected as previously described by O'Rourke and others $(1998 \mathrm{a}, \mathrm{b})$. Anaesthetic levels appeared to be equivalent for the biopsy protocol with either the proparacaine eye drops or the histamine/proparacaine combination eye drops. Eyelid sections from the samples were stained by automated immunostaining (Ventana Medical Systems) using the monoclonal antibodies $99 / 97.6 .1$ and $89 / 160.1 .5$ at $10 \mu \mathrm{g} / \mathrm{ml}$, as previously described by O'Rourke and others (2000). Positive staining of the third eyelid lymphoid tissue was identified as red extracellular and cytoplasmic staining in germinal centres of the lymphoid follicles (Fig 1). The third eyelid sections were also stained by routine haematoxylin and eosin.

After the application of histamine, the lymphoid tissue of the right third eyelid increased in apparent size relative to the left third eyelid (Fig 2). Four of the five sheep tested positive for $\operatorname{Pr} \mathrm{PSc}^{\mathrm{S}}$ in the lymphoid follicles of the left and right third eyelids by immunohistochemical analysis. These results indicate that histamine does not interfere with $\mathrm{PrPSc}$ detection in the lymphoid follicles of the third eyelid (Fig 1). Haematoxylin and eosin staining of the third eyelid sections revealed increased oedema in the third eyelids treated with histamine, without appreciable changes to the lymphoid follicles (Fig 3 ).

In the USA, proparacaine is an approved veterinary drug for all species and histamine is approved for human use. Using proparacaine together with histamine does not pose a problem, as a drug approved for use in human beings can be used in food animals if there is no equivalent approved veterinary drug. As always, a valid veterinary/client/patient relationship must be established first before any treatment is initiated (M. M. Robinson, personal communication). Both proparacaine and histamine are licensed for medical use in the UK, but veterinary practitioners would need to contact the Department of the Environment, Food and Rural Affairs before using these drugs in veterinary applications. Alternatively, a special treatment authorisation to import the Vetricare product could be obtained.

Histamine is present in mast cells in all body tissues. When released from mast cells, it causes vasodilation and an increase
Veterinary Record (2004) $154,662-663$

\section{S. Bender, DVM} Navajo Nation

Veterinary Program, Chinle, AZ 86503-1623, USA

J. Alverson, $\mathrm{DVM}, \mathrm{PhD}$

L. M. Herrmann, $\mathrm{PhD}$,

K. I. O'Rourke, PhD,

USDA, ARS, Animal

Disease Research

Unit, Pullman,

WA 99164-6630, USA

Correspondence to Dr Alverson 
(a)
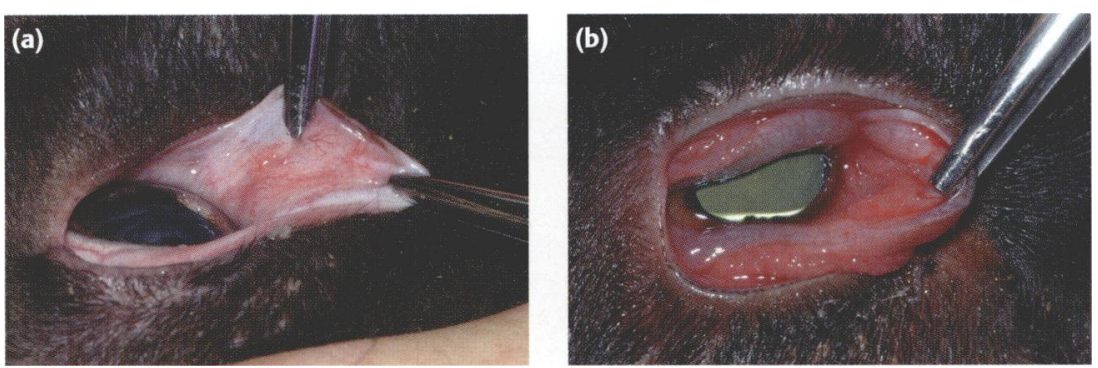

FIG 2: Third eyelid treated with (a) 0.5 per cent sterile ophthalmic proparacaine hydrochloride eye drops with no histamine, and (b) an eye drop formulation of 1 per cent histamine and 0.5 per cent proparacaine hydrochloride
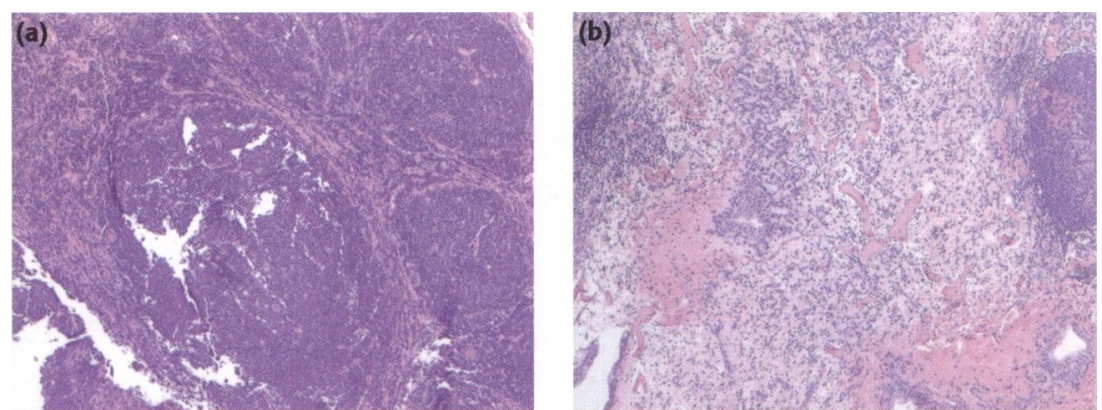

FIG 3: Staining of third eyelid lymphoid tissue sections showing increased oedema in (a) third eyelids treated with histamine, compared with (b) third eyelids without histamine treatment, without appreciable changes to the lymphoid follicles.

Haematoxylin and eosin. $\times 40$ scrapie by immunohistochemistry of third eyelid lymphoid tissue. Journal of Clinical Microbiology 38, 3254-3259

O'ROURKE, K. I., BASZLER, T. V., MILLER, J. M., SPRAKER, T. R., SADLERRIGGLEMAN, I. \& KNOWLES, D. P. (1998a) Monoclonal antibody F89/160.1.5 defines a conserved epitope on the ruminant prion protein. Journal of Clinical Microbiology 36, 1750-1755

O'ROURKE, K. I., BASZLER, T. V., PARISH, S. M. \& KNOWLES, D. P. (1998b) Preclinical detection of $\mathrm{PrP}^{\mathrm{Sc}}$ in nictitating membrane lymphoid tissue of sheep. Veterinary Record 142, 489-491

O'ROURKE, K. I., DUNCAN, J. V., LOGAN, J. R., ANDERSON, A. K., NORDEN, D. K., WILLIAMS, E. S., COMBS, B. A., STOBART, R. H., MOSS, G. E. \& SUTTON, D. L. (2002) Active surveillance for scrapie by third eyelid biopsy and genetic susceptibility testing of flocks of sheep in Wyoming. Clinical and Diagnostic Laboratory Immunology 9, 966-971

PRUSINER, S. B. (1982) Novel proteinaceous infectious particles cause scrapie. Science 216, 136-144

SCHREUDER, B. E. C., VAN KEULEN, L. J. M., VROMANS, M. E. W., LANGEVELD, J. P. M. \& SMITS, M. A. (1996) Preclinical test for prion diseases. Nature 381, 563

THURING, C. M. A., MCELROY, M. C., SWEENEY, T. \& WEAVERS, E. (2000) Suitability of protuberances on the third eyelids of sheep as a biopsy site for lymphoid follicles. Veterinary Record 147, 631-632 in the permeability of the blood vessel walls. This was evident in the third eyelid lymphoid tissue, with increased in apparent size after histamine treatment, as well as the oedema noted upon microscopic evaluation. There was no evidence that the use of histamine in the eye drop formulation compromised the welfare of the animals observed in this study.

In summary, histamine-containing eye drops improved biopsy collection of third eyelid tissue, with increased numbers of lymphoid follicles, and did not interfere with immunohistochemical detection of $\mathrm{PrP}^{\mathrm{Sc}}$. The use of histamine-containing eye drops would therefore greatly increase the accuracy of preclinical scrapie diagnosis using third eyelid tissue.

\section{ACKNOWLEDGEMENTS}

The authors are grateful to C. Leathers for pathology expertise; T. Truscott for technical assistance; H. Moore for photographic assistance; P. Steiner, D. Chandler and R. Finch for animal care; and J. V. Duncan, of USDA, APHIS, Veterinary Services, for excellent training in the biopsy technique.

\section{References}

FRASER, H. (1976) The pathology of a natural and experimental scrapie. Frontiers of Biology 44, 267-305

IKEGAMI, Y., ITO, M., ISOMURA, H., MOMOTANI, E., SASAKI, K., MURAMATSU, Y., ISHIGURO, N. \& SHINAGAWA, M. (1991) Preclinical and clinical diagnosis of scrapie by detection of PrP protein in tissues of sheep. Veterinary Record 128, 271-275

MURAMATSU, Y., ONODERA, A., HORIUCHI, M., ISHIGURO, N. \& SHINAGAWA, M. (1993) Detection of PrP $\mathrm{Psc}^{\mathrm{si}_{\mathrm{c}}}$ in sheep at the preclinical stage of scrapie and its significance for diagnosis of insidious infection. Archives of Virology 134, 427-432

O'ROURKE, K. I., BASZLER, T. V., BESSER, T. E., MILLER, J. M., CUTLIP, R. C., WELLS, G. A. H., RYDER, S. J., PARISH, S. M., HAMIR, A. N., COCKETT, N. E., JENNY, A. \& KNOWLES, D. P. (2000) Preclinical diagnosis of 